\section{Цитування:}

Gonchar O., Soboliev O., Tokar M., Lytvyniuk L. Generalization of arts: poetry and illustration [Генералізація мистецтв: поезія і ілюстрація]. Вісник Національної академії керівних кадрів культури і мистещтвв : наук. журнал. 2020. № 3. C. 55-60.

Gonchar O., Soboliev O., Tokar M., Lytvyniuk L. (2020). Generalization of arts: poetry and illustration. National Academy of Culture and Arts Management Herald: Science journal, 3, 55-60 [in Ukrainian].

\author{
Gonchar Olena, \\ Doctor. Sci. (Education), Professor, Kharkiv State \\ Academy of Design and Arts, Pro-rector of \\ Scientific Research and International Relations \\ ORCID: https://orcid.org/0000-0003-1122-1768 \\ helelenushka072@gmail.com \\ Soboliev Oleksandr, \\ Ph.D. (Design), Professor, Kharkiv State Academy \\ of Design and Arts, Vice-Rector \\ ORCID: https://orcid.org/0000-0001-6771-1673 \\ sobolev.av@ukr.net \\ Tokar Maryna,
}

Ph.D. (Arts), As. Prof., Kharkiv State Academy of

Design and Arts, Dean of Visual Arts Department

ORCID: https://orcid.org/0000-0002-3666-0604

mari4katokar@gmail.com

Lytvyniuk Liudmyla,

Candidate of Art, Associate Professor of the

Graphic design Department

Kharkiv State Academy of Arts and Design

ORCID: https://orcid.org/0000-0002-3412-463X

litvinuklk@gmail.com

\title{
GENERALIZATION OF ARTS: POETRY AND ILLUSTRATION
}

The purpose of the article is to define the conception of perception of poetic texts and illustrations by generalizing these forms of arts. The methodology is based on the functional approach to verbal and non-verbal text comprehension. The scientific novelty of the work lies in understanding the process of generalization of two forms of arts, such as poetry and illustration that proves the idea of their twofold nature. The developed typology of poetic texts with a basic parameter "antithesis" and classification of the forms of illustrations are founded on the correlation of projecting and conceptual principles of reality reflection in verbal and non-verbal texts, and on the explicitness degree of evaluative characteristics. Conclusion. The generalization of two forms of arts contributes to developing a course of action for an artist-illustrator. The significance of the scientific research results can clarify the elements of ambiguity, uncertainty, obscurity in the process of perception of any work of arts.

Key words: work of art, illustration, poetic text, functional approach, generalization, perception.

Гончар Олена Валентинівна, кандидат філологічних наук, доктор педагогічних наук, професор, проректор з науково-дослідної роботи Харківської державної академії дизайну $і$ мистеитв; Соболєв Олександр Валерійович, кандидат мистеитвознавства, професор, графік-дизайнер, перший проректор $з$ науково-педагогічної роботи Харківської державної академії дизайну і мистеитв; Токар Марина Іванівна, кандидат мистецтвознавства, доцент, декан факультету аудіовізуального мистеитва Харківської державноі академії дизайну і мистеитв; Литвинюк Людмила Костянтинівна, кандидат мистеитвознавства, доиент кафедри графічного дизайну Харківської державної академії дизайну і мистеитв

Генералізація мистецтв: поезія і ілюстрація

Метою статті $\epsilon$ визначення концепції комплексного сприйняття поетичного тексту та ілюстрацій до нього шляхом узагальнення цих двох форм мистецтва. Методологія грунтується на функціональному підході до сприйняття вербального та невербального тексту. Наукова новизна роботи полягає у дослідженні процесу сприйняття тексту через розуміння синтезу двох форм мистецтва, поетичного тексту та ілюстрації, що доводить ідею їх подвійної природи. В основу запровадженої типологія поетичного творів з базовим параметром «антитеза», яку подано в кореляції із розробленою класифікацією форм ілюстрацій, покладено співвідношення проективного й концептуального принципів відображення дійсності у вербальному та невербальному текстах, ступень експліцитності оцінок. Висновки. Співвідношення типів поетичного тексту із формами ілюстрацій

(C) Gonchar O., 2020

(C) Soboliev O., 2020

(C) Tokar M., 2020

(C) Lytvyniuk L., 2020 


\section{Мистецький простір: історія та сучасність Gonchar O., Soboliev O., Tokar M., Lytvyniuk L.}

сприяє вдосконаленню методики роботи художника-ілюстратора. Результати наукового дослідження можуть також бути використані для з'ясування елементів, які породжують неоднозначність та невизначеність процесу сприйняття будь-якого твору мистецтва.

Ключові слова: витвір мистецтва, ілюстрація, поетичний текст, функціональний підхід, узагальнення, сприйняття.

Гончар Елена Валентиновна, кандидат филологических наук, доктор педагогических наук, профессор, проректор по научно-исследовательской работе Харьковской государственной академии дизайна и искусств; Соболев Александр Валерьевич, кандидат искусствоведения, профессор, график-дизайнер, первый проректор по научно-педагогической работе Харьковской государственной академии дизайна и искусств; Токарь Марина Ивановна, кандидат искусствоведения, доцент, декан факультета аудиовизуального искусства Харьковской государственной академии дизайна и искусств; Литвинюк Людмила Константиновна, кандидат искусствоведения, доцент кафедры графического дизайна Харьковской государственной академии дизайна и искусств

Генерализация искусств: поэзия и иллюстрация

Целью статьи - определить концепцию комплексного восприятия поэтического текста и иллюстраций к нему путем обобщения этих двух форм искусства. Методология исследования основывается на положениях функционального подхода к пониманию вербального и невербального текста. Научная новизна работы заключается в исследовании процесса восприятия текста посредством осмысления синтеза двух форм искусства, поэтического текста и иллюстрации, что доказывает идею их двойственной природы. В основу созданной типологии поэтических произведений с базовым параметром «антитеза», представленной в корреляции с разработанной классификацией форм иллюстраций, положено соотношение проективного и концептуального принципов отражения действительности в вербальном и невербальном текстах, степень експлицитности оценки. Выводы. Соотношение типов поэтического текста с формами иллюстраций способствует совершенствованию методики работы художника-иллюстратора. Результаты научного исследования могут также быть использованы для уточнения элементов, порождающих неоднозначность и неопределенность процесса восприятия любого произведения искусства.

Ключевые слова: произведение искусства, иллюстрация, поэтический текст, функциональный подход, обобщение, восприятие.

Introduction. The modern system of arts is an area of intersection of various types of artistic creativity. The emergence of new types of visual practices, the development of computer technology raises new questions about the relationship between old and new kinds and forms of arts, and also presents the full depth of the aesthetic needs of modern society.

The complex study of artworks and their interpretation has been a controversial and muchdisputed subject within the field of arts. A large and growing body of literature has investigated the problem of the preferable tendency, whether it should be the stream for the synthesis of arts, on the one hand, or the independence of each individual art, on the other. Even in the Bible, there are indications of a similar contradiction reflecting, to a certain extent, in different historical periods. At the dawn of civilization in the primitive communal system, there were signs of a complex character of man's creativity, activities, and thinking. In ancient Egypt, it became customary to present spells and hymns on papyrus accompanied by images.

Both reading literary works [2] and watching visual artworks [4] presuppose cognitive, visual, evaluative, effective processing. So far, however, there has been little discussion about the perception, interpretation of a poetic text and its illustrations by the generalization of these forms of arts.

The study attempts to define the concept of perception of poetry and illustrations by generalizing these forms of arts. The questions addressed in the research are:

1. What is an effective way of setting up the typology of poetic texts determined by a functional analysis of lexical micro-systems (paradigms) in the framework of the functional approach to text perception?

2. What is the specificity of the generalization of the arts?

3. What forms of illustrations can be singled out in correlation with the defined typology of poetic texts?

2. Methodology. The methodological basis of the study was the philosophical position on the inextricable connection of language, thinking, perception, and reality. Within the framework of a functional approach to the problem of analysis of art or poetic texts (M. Berns (1990) [1], M. Halliday (1990) [3], Yu. Lotman (1998) [11], A. Levitskiy (2010) [9], O. Lisina (1998) [10], M. Pravdin (1991) [12], Yu. Sorokin (1985) [13], I. Stepanchenko (1990) [14], A. Zalevskaya (1981) [7] ) the theoretical propositions of this paper concern the existence of certain text models. The variety of concepts of the text content can be reduced to two main directions: static and 


\section{Вісник Національної академії керівних кадрів культури і мистецтв № 3’2020}

dynamic. In this study, we use a functionaltypological approach relating to a dynamic direction, so a text is considered as a unit of a communicative act.

The basis of the functional approach is a certain model of a text, which involves the mechanism of its perception as a process of binding the linguistic units and units of thinking in a recipient's mind. Thus, the perception of the text occurs in his mind on two levels of the content structure - linguistic and non-linguistic. According to this approach, the content of the text is a thinking process of transition from verbal images (the image of the material form of the word, the sequence of letters or sounds) to other verbal and non-verbal ('subject') images, phenomena and situations of non-textual reality. In comparison, the content of any visual artwork is a process of thinking, the transition from visual images (the image of the material form of an illustration, the sequence of visual signs) to other verbal and non-verbal ('subject') images. An illustration is a unique kind of art that provides a visual interpretation of the author's concept.

Main Part. 1. What parameter can be basic in setting up the typology of poetic texts in the framework of a functional approach to their analysis?

According to two types of images, there are two levels of the content structure of the text, such as the linguistic (the level of operation of verbal images) and the mental or figurative-conceptual level of operation of "substantive" images and concepts.

In the recipient's mind, there is a formation of ties between the text and reality, which can be established both at the level of the image (a specific level) and at the level of connections between the images, the concept (abstract level). Here, there are two different (distinct) but, simultaneously, closely interrelated principles of reflection of reality in the text. The proportion of the specific weight of projective (images) and conceptual elements in poetic texts, varying, determines the specificity of functioning and its affiliation to one or another type of texts: mainly projective or mainly conceptual one. So, the peculiar 'algorithm' defining the process of perception is the structural organization of the art (in this case, poetic) text, which involves the joining text units together in paradigms, and the presence or absence of an explicit estimation.

Thus, within the framework of text study in the focus of attention, there are different interacting with each other lexical paradigms which are formed in the reader's mind in the process of the text perception at the level of 'object' images and relationships between them.
The parameter 'antithesis', singled out as a 'basic' one, serves as a basis for the development of the typology of texts. This allows consideration of the vocabulary of a poem as a system of rows (paradigms) that reinforce one or another side of the main contradiction of the poetic work.

The category of antithesis is a modification of the category of collision singled out in literary criticism that is the dialectical contradiction existing in the development of a plot of any work "confrontation, a contradiction between characters and circumstances, and other forces acting in the work" [15]. Individuality, the uniqueness of collisions, as a result, determines the peculiarity of a collision of an artwork. The collision organizes the content of a work of any genre, including a lyrical, but in this case, the 'collision' is not so much the basis of action as "the movement of experiences here is not always obvious" [8].

Hence, according to the correlation between the projective and conceptual principles of reflection of reality in a text and the level of explicitness of the paradigm of estimation the proposed typology comprises different types of antitheses. The antithesis develops in different ways, depending on which of the principles of reflection of reality prevails. Poetic works of a predominantly conceptual nature presuppose the implementation of two types of antithesis: ANTITHESIS-CONFLICT AND ANTITHESISANTINOMY. Here the role of the estimated paradigm is important. So, in poems based on ANTITHESIS-CONFLICT, as a rule, there are clearly presented estimation accents that allow the reader to determine the author's opinion, while the antithesis may remain unresolved.

The second type of antithesis is ANTITHESIS-ANTINOMY. The opposing interconnected origins making up the hull of this type of poem do not find a solution either within a particular poem or within the cycle as a whole. [14] The lack of unambiguous evaluative characteristics of one of the two sides of the antithesis shows an uncertain author's opinion.

A characteristic feature of ANTITHESISSITUATION is the possibility of its implementation in verbal texts of a mainly projective nature. In such poetic works, the relationship of reality with the text in the recipient's mind is carried out on the mainly visuallprojective level. The nature of its meaning content is purely variational. The opposite interconnected starts may appear in various modifications, namely: statics - dynamics, color contrasts (black-white, colored), etc. Hegel defines such a "situation" as a description of a certain state that "has no subsequent consequences" $[6,204]$, where conceptuality goes 
back to the background, as less significant, secondary.

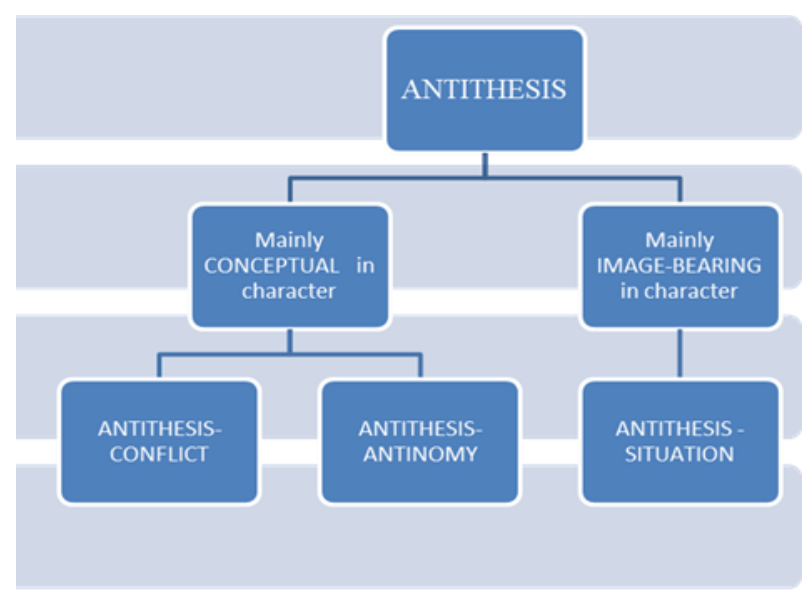

Table 1: Typology of poetic texts in the framework of a functional approach to their analysis.

2. What is the specificity of the generalization of the arts? While reading of any artistic work, each reader perceives its meaning and describes characters or events in his or her own way, depending on the personal background knowledge, experience, the system of value orientations, readiness for empathy, etc. This raises the question of the quality of an illustrator's work, often a graphic artist, since his work is, in a certain way, an intrusion on the author's idea, and on a personal variant of its perception by each reader. Any illustration begins to influence the perception of readers by imposing the illustrator's vision, thereby violating the associative space left by the author of the poem for the free imagination of the recipients. Thus, one can speak of the existence of the interaction of arts. Such a generalization of these two arts makes it possible and explains the emergence of a new work of art with a plurality of new variants of its perception. Another form gets the right to life through the conception of generalization with the so-called congenial art, which is one that does not have specific, substantive artistic qualities. Here the problem field lies in the sphere of the activity of the artists who establish the options of font, ornament, general style, etc. And in fact, it is the artists who implement them.

Additionally, the problem of the interaction of arts lies in the fact that such generalization affects the process of co-creation of the author of the work with its reader which is already directly mediated by the text itself. Perception of a poetic work through the prism of illustration can either enrich or, conversely, impoverish the associative field of readers. Thereby it affects the quality and the number of variants of an essentially new reality of a new version of the poetic text. Thus, such a process generates a new personalized unified creative product.

3. Against this background, touching on the problem of illustration of art (poetic) works, one can note the correlation of the choice of forms of illustration to the typology of antitheses. An author of a poetic text comes into co-creation with each reader, spreading the associative circle and generating the number of new variants of reality. Thus, the illustration can open new ways to realize the idea of the poem, its additional comprehension, and the reproduction of visual images. Such a newly created variant is not one of those which were subject to the process of generalization.

And, on the contrary, the illustration, playing the role of the forerunner, narrows the associative field, throwing out its vision, imposing its version of perception. Although the modern graphic already possesses a sufficiently wide range of possibilities to create a certain equivalent version of an artistic (poetic) work, ut all the same, it is just one option. But any illustration is much poorer than several variants that may occur to a reader's mind because of his ability to create or reproduce images graphically on the basis of complicated combinations of different associations.

In accordance with the relationship of projecting and conceptual principles of reality reflection in verbal and non-verbal texts, and on the explicitness degree of evaluative characteristics such as theoretical items, there can be worked out the classification of forms of illustration. Taking into consideration the generalization of two kinds of arts, poetry, and illustration, such classification can be correlated with the types of poetic antisepsis.

The first form involves strict imitation of the author's ideas by an artist, such as the reproduction of the characters' appearance, description of the city, and the situation where events took place, etc. The artist tries to position himself as the "decoder" of the information, without touching on the author's style, characteristics of the heroes, the main idea of the work or psychological atmosphere, etc. This form of illustration seeks for historical and visual accuracy, with high correspondence to the objective reality at the projective level. It does not impose an ideological-stylistic or artisticplastic component. Such illustration does not reduce the high level of co-creation of the reader and the author of the poetic work, but only opens new associative vectors. An illustrator's background knowledge helps him to clarify the projective image. That facilitates the perception of the text for representatives of another culture. This form of illustration correlates more often to the 


\section{Вісник Національної академії керівних кадрів культури і мистецтв № 3’2020}

poetic texts that belonged to the ANTITHESISSITUATION type. A great example of such a correlation can serve an illustration by $\mathrm{E}$. Kapustin to the poem 'A White Birch' by the Russian poet S.Yesenin. The second form covers the illustrations appealing to the implicit level of perception. When creating such illustrations an artist-illustrator is more affected by the subtext of a poetic text. Thus, for the proper transmission of the main idea, of the style of the poetic work the illustrator faces a problem of choice of art means of presentation, namely, the use of etching (eau forte, Italian acquaforte, aquaculture, pencil drawing, engraving techniques or computer graphics, etc.). The illustrator uses all the visual arts resources, complicates the illustration by detailing it in order to reveal the idea of the work and pull out the implicit author's estimates onto the surface. This form of illustrations correlate with the ANTITHESIS-CONFLICT, which implies an unambiguous uniqueness at the conceptual level, and the variability of associations on the projective one. A successful example of such a correlation can become an illustration by E. Kurbatov to the sonnet 90 by outstanding English poet W. Shakespeare.

The third form of illustration mainly correlates to the poetic texts of the ANTITHESISANTINOMY type. It differentiates with the use of a pictorial metaphor, full of mediated, sometimes contradictory images. Here much depends on the level of development of the illustrator's general abilities (imagination, verbal ability, color sensitivity, a type of verbal-logical thinking, ability to analyze), his experience, systems of values, and background knowledge. Thus, both projective and conceptual images of the poem are becoming important in turn. Here comes the illustration which is mainly peculiar to the poetic texts with a practically hidden or shaded storyline or plot. Nowadays, one can argue for everyday considerable increase of the humanly possible associations. The modern poem has become trickier. Thus, both projective images and a plotline of the poem are becoming less important. An illustration, full of symbolic hints or signs, touches the poetic lines in passing. The range of casual, purely metaphorical images opens to the reader a boundless space of perception of the poetic work at all the levels. Such illustrations can be connected with the definite verbal text only through very soft and even strange associations. An interesting example of such a correlation is an illustration by the modern Ukrainian illustrator and artist Kh. Lukashchuk to the poem 'Swim, Fish, Swim...' by the young talented Ukrainian poet S. Zhadan.

It can therefore be assumed that the upper suggested correlations are conventional in character, so the mechanism of creation of possible variants and combinations is the tool of an illustrator. Scientific novelty and conclusions. Hence, the developed typology of poetic texts with a basic parameter "antithesis" and classification of the forms of illustrations are founded on the correlation of projecting and conceptual principles of reality reflection in verbal and non-verbal texts, and on the explicitness degree of evaluative characteristics. Such a generalization of two kinds of arts can become the basis for improvement of verbal and non- verbal perception and contributes to the work of graphic artists, illustrators of poetic works. Therefore, both explicitly expressed judgments showing the uniqueness of the perception of poems at the conceptual level (ANTITHESIS-CONFLICT) and their variable perception at the projective level emphasize a poet's certain point of view (for example, obedience to fate or, on the contrary, determination). Conversely, implications, the ambiguity of evaluative characteristics at the conceptual level (ANTITHESIS-ANTINOMY) makes it possible to feel duality, the uncertainty of sight, hearing, sensation, conceptual variability of poetics. In addition, an illustration often reveals a poet's idea by appealing to sensory experience and affect the memory of a reader. The process of generalization of two forms of arts, such as poetry and illustration, proves the idea of their twofold nature, understanding the mechanism of which helps the comprehensive perception of verbal and non-verbal texts. The results presented in the work need further development since the interrelation of literature and illustration only emphasizes the opening of new spaces for the appearance of variants of their perception by a recipient (reader, viewer, and listener). However, more theoretical research and experimental verification on this topic to be undertaken before the problem of synthesis of arts is clearly understood. The proposed typology of 'antithesis' correlated with the forms of illustration is only an initial stage in realizing the process of generalization and perception of arts. The practical significance of the results of scientific research in the given aspect can be used to clarify the elements of ambiguity, uncertainty, obscurity in the process of perception of any work of arts. The results can be useful in scientific research on the history and theory of arts, problems of perception of a poetic text within the improvement of the practice of linguistic-stylistic text analysis. The correlation of the poetic text types (antithesis typology) with the forms of illustrations contributes to developing a course of action for an artist-illustrator. Thus, future studies on the current topic are therefore recommended. 


\section{Лimepamypa}

1. Berns M. Functional Approaches to Linguistics. Contexts of Competence / Berns M. Topics in Language and Linguistics. Springer, Boston, MA, 1990. URL: https://doi.org/10.1007/978-1-4757-98388_1 (07.05.2019).

2. Jacobs A. Neurocognitive poetics: methods and models for investigating the neuronal and cognitive affective bases of literature reception. Frontiers in Human Neuroscience. 2015. No. 9. P. 186. URL: http://dx.doi.org/10.3389/fnhurn.2015.00186 (07.05.2019).

3. Halliday M.A.K. An Introduction to Functional grammar. London : Edward Arnold. 1990.

4. Leder H., Oeberst A. \& Augustin D. A model of aesthetic appreciation aesthetic judgement. British Journal of Psychology. 2004. No. 95(4), pp. 489-508. URL: http://dx.doi.org/10.1348/0007126042369811 (07.05.2019).

5. Выготский Л. С. Психология искусства. Москва : Искусство, 1986. 573 с.

6. Гегель Г. В. Ф. Лекции по эстетике : пер. с нем. Санкт-Петербург : Наука, 1999. С. 204.

7. Залевская А. А. О комплексном подходе к исследованию закономерностей функционирования языкового механизма человека / А. А. Залевская. Психолингвистические исследования в области лексики и фонетики. Калинин, 1981. С. 28-44.

8. Краткая литературная энциклопедия : в 9 т. / Под ред. А. А. Суркова. Москва : Советская энциклопедия, 1966. Т. 3. С. 657.

9. Левицкий А. Э. Функциональный подход в современной лингвистике. Studia Linguistica: зб. наук. праць. Київ : ВПЦ «Київський університет», 2010. Вип. 4. С. 31-38.

10. Лісіна О. В. Зіставний аналіз лексики ідіостилів С. Єсеніна й імажиністів : автореф. дис. на здобуття ступеня канд. філол. наук: 10.02.02. Харків : ХДПУ ім. Г. С. Сковороди, 1998. 16 с.

11. Лотман Ю. М. Об искусстве. СанктПетербург : «Искусство —- СПБ», 1998. 704 с.

12. Правдин М. Н. Проблема абстрактного и конкретного в мышлении и языке. Москва : Вдохновение, 1991. 229 с.

13. Сорокин Ю. А. Психолингвистические проблемы восприятия и оценки текста. Москва, 1985. $167 \mathrm{c}$.

14. Степанченко И. И. Поэтический язык Сергея Есенина: анализ лексики. Харьков : б. и., 1991. $189 \mathrm{c}$.

15. Філософський енциклопедичний словник / НАН України, Ін-т філософії ім. Г. С. Сковороди ; редкол. : В. І. Шинкарук (голова) та ін. Київ : Абрис, 2002. 742 с.

\section{References}

1. Berns, M. (1990). Functional Approaches to Linguistics. In: M. Berns. Contexts of Competence. Topics in Language and Linguistics. Springer, Boston, MA Retrieved from https://doi.org/10.1007/978-14757-9838-8_1 [in English].

2. Jacobs, A. (2015). Neurocognitive poetics: methods and models for investigating the neuronal and cognitive-affective bases of literature reception. Frontiers in Human Neuroscience, 9, 186. Retrieved from http://dx.doi.org/10.3389/fnhurn.2015.00186 [in English].

3. Halliday, M.A.K. (1990.) An Introduction to Functional grammar. London: Edward Arnold [in English].

4. Leder, H., Oeberst, A. \& Augustin, D. (2004). A model of aesthetic appreciation aesthetic judgement. British Journal of Psychology, 95(4), 489-508. Retrieved from http://dx.doi.org/10.1348/0007126042369811 [in English].

5. Vygotskiy, L. S. (1986). Psychology of art. Moscow : Iskusstvo [in Russian].

6. Hegel, G. (1999). Lectures on Aesthetics. (pp. 204). St. Petersburg : Nauka [in Russian].

7. Zalevskaya, A. A. (1981). On an integrated approach to the study of patterns of functioning of the human language mechanism. In A. A. Zalevskaya. Psycholinguistic studies in the field of vocabulary and phonetics. Kalinin [in Russian].

8. Surkov, A. A. (Ed.). (1966). Short literary encyclopedia. (Vol. 3), (pp. 657). Moscow: Sovetskaya entsiklopediya [in Russian].

9. Levitskiy, A. E. (2010). Functional approach in modern linguistics. Studia Linguistica. (Issue 4), (pp. 31-38). Kyiv: Kyiv: VPTs «Kyivskyi universytet» [in Russian].

10. Lisina, O. V. (1998). Comparative analysis of vocabulary of idiostyles by S. Yesenin and Imaginists. Extended abstract of candidate's thesis. Kharkiv: KhDPU im. H. S. Skovorody [in Ukrainian].

11. Lotman, Yu. M. (1998). About art. St. Petersburg : «Iskusstvo - SPB» [in Russian].

12. Pravdin, M. N. (1991). Problem of abstract and concrete in thinking and language. Moscow: Vdokhnovenie [in Russian].

13. Sorokin, Yu. A. (1985). Psycholinguistic problems of perception and evaluation of the text. Moscow [in Russian].

14. Stepanchenko, I. I. (1991). Sergey Esenin's poetic language (the lexicon analysis. Kharkiv: N. ed. [in Russian].

15. Shynkaruk, V. I. et al. (Eds.). Philosophical Encyclopedic Dictionary. Kyiv: Abris [in Ukrainian]. 